\title{
Laporan Kasus: Tindakan Enukleasi Bulbi Akibat Ophtal Myasis pada Anjing Pomeranian
}

\author{
Case Report: Enucleating Bulbi Due To Ophthal Myasis In Pomeranian Dogs
}

\author{
Suryaningrum $^{1 *}$, Faisal Fikri ${ }^{2}$ \\ ${ }^{1}$ Bachelor of Veterinary Medicine, \\ ${ }^{2}$ Department of Basic Veterinary Science, \\ Faculty of Veterinary Medicine, Universitas Airlangga, \\ UNAIR C-Campus Mulyorejo, Surabaya, East Java, Indonesia 60115 \\ *Corresponding author: dokec17@gmail.com
}

\begin{abstract}
Abstrak
Seekor anjing ras Pomeranian, bernama Kino, berumur tiga tahun, dan berjenis kelamin jantan, datang ke klinik dengan keadaan mata kanan telah menggelap, terdapat koloni larva, dan berbau busuk. Berdasarkan anamnesis dari pemilik anjing dan hasil dari pemeriksaan fisik, hewan didiagnosa mengalami ophtal myasis. Tindakan yang diambil untuk menangani kasus ini adalah tindakan operatif enukleasi bulbi. Terapi sistemik pasca tindakan operasi dengan memberikan Dexamethasone dan Ceftriaxone injeksi intra muskularis, serta pemberian terapi per oral menggunakan kombinasi obat: Methylprednisolon, Ketoprofen, Adona, Cefadroxil, dan Heptasan. Proses pemulihan anjing membutuhkan waktu 14 hari.
\end{abstract}

Kata kunci: anjing, enukleasi bulbi, ophtal myasis

\begin{abstract}
A three years old male Pomeranian dog named Kino, came to the clinic with darkening right eye, larval colonies, and foul-smelling. Based on the history of the dog owner and the results of the physical examination, the animal was diagnosed with ophtal myasis. The operative action performed to treat with the case is bulbi enucleation. Systemic therapy after surgery by giving intra-muscularis Dexamethasone and Ceftriaxone injection, and giving oral therapy using a combination of few drugs: Methylprednisolon, Ketoprofen, Adona, Cefadroxil, and Heptasan. The dog's recovery process takes 14 days.
\end{abstract}

Key words: dog, bulbi enucleation, ophtal myasis

Received: 17 Maret 2019

Revised: 13 Mei 2019

Accepted: 9 Juli 2019

\section{PENDAHULUAN}

Bulan Juli 2018, seekor anjing ras Pomeranian berumur 3 tahun, berjenis kelamin jantan dibawa ke Klinik Hewan Sahabat Satwa oleh klien untuk memeriksakan keadaan anjingnya. Berdasarkan anamnesis yang diperoleh dari klien, anjing Kino dipelihara menggunakan kandang individu, setiap hari dilepas dari kandang pada jam 8-10 pagi dan rutin dimandikan satu minggu sekali. Selama pemeliharaan, pakan yang diberikan adalah $d r y$ food dua kali sehari. Pemberian vaksin dan obat cacing rutin dilakukan. Diketahui anjing tersebut mengalami trauma pada mata sebelah kanan yang diakibatkan tertusuk kawat pada kandangnya dan klien terlambat menyadari adanya trauma pada mata kanan anjing, akibatnya luka pada mata sebelah kanan menjadi tempat investasi lalat sehingga pada pemeriksaan fisik yang dilakukan, ditemui adanya koloni larva lalat dan telah mengeluarkan aroma busuk (Gambar 1).

Berdasarkan pemeriksaan fisik yang dilakukan pada anjing tersebut diperoleh hasil berupa suhu tubuh sebesar $39,8^{\circ} \mathrm{C}$, frekuensi pulsus $107 \mathrm{kali} /$ menit, frekuensi nafas sebanyak 27 kali/menit, turgor normal, dan refleks pupil mata sebelah kiri normal. 
Berdasarkan anamnesis dan hasil dari pemeriksaan fisik yang telah dilakukan, diagnosa anjing Kino mengalami ophtal myasis pada mata sebelah kanan. Myasis merupakan invasi jaringan vertebrata oleh larva dari ordo Diptera (Berenji et al., 2015). Ophtal myasis sering terjadi akibat komplikasi myasis hidung dan mulut, tetapi dapat terjadi secara sendiri. Apabila ophtal myasis terlambat dalam mengobati maka larva mampu menghancurkan seluruh bola mata (Wardhana, 2006).

Myasis merupakan infestasi larva lalat pada vertebrata untuk periode tertentu dari siklus hidupnya, larva akan memakan jaringan inang, cairan tubuh atau makanan yang dicerna (Zumpt, 1965). Mullen et al.,(2001) menyatakan myiasis merupakan salah satu gangguan yang menjadi masalah utama kesehatan maupun ekonomi.

Opthal myasis terjadi akibat adanya infestasi larva lalat pada mata maupun adneksa ocular (Wakamatsu and Pierro, 2006). Kasus ophthal myasis rawan terjadi pada anjing yang dipelihara di lingkungan kotor dan lembab. Larva myasis pada anjing dapat termasuk luka gigitan, area bulu yang kotor, liparan kulit, telinga dan mata yang terinfeksi (Shinohara et al., 2004). Francesconi dan Lupi (2012), menyatakan ophtal myasis diklasifikasikan menjadi ophtal myasis eksterna, dan ophtal myasis interna.

Salah satu teknik operasi pada mata adalah enukleasi, dengan melakukan pembedahan pada area mata dengan tujuan untuk mengangkat bola mata dengan memotong jaringan-jaringan dan syaraf yang ada di dalamnya (Wyman et al., 2007). Enukleasi dapat dilakukan dengan pertimbangan jika bola mata sudang mengalami kerusakan total dan tidak memungkinkan untuk mengembalikan keadaan anatomi seperti semula. Berdasarkan pernyataan Mitchell (2008), teknik enukleasi memiliki empat teknik, diantaranya exenterasi; trans-konjungtiva; trans-palpebrae; dan prosthesis ocular.

\section{METODE PELAKSANAAN}

\section{Alat dan Bahan}

Berdasarkan diagnosa yang didapat maka dapat dilakukan tindakan enukleasi bulbi pada anjing Pomeranian. Instrumen yang digunakan dalam tindakan operasi meliputi gunting Metzembaum bengkok, blade no. 23 dan scalpel, pinset chirurgis, pinset anatomis, chromic catgut no. 03 dan no.02, needle, needle holder, arteri klem bengkok, cautter, spuit with needle, under pad, kapas dan kasa steril, cairan $\mathrm{NaCl}$ fisiologis, serta anastesi.

\section{Metode Tindakan}

1) Prosedur premedikasi dilakukan dengan menggunakan atropin sulfat (Atropin sulfate $^{\circledR}$, Eticha, Indonesia) dengan dosis $0,22-0,44 \mathrm{mg} / \mathrm{Kg}$ BB melalui injeksi intra muscular, selang waktu 15 menit diberikan acepromazine $\quad\left(\right.$ Castran $^{\circledR}, \quad$ Hollanddengan dosis $0,03-0,05 \mathrm{mg} / \mathrm{kg}$ BB melalui intra muscular;

2) Prosedur anastesi dilakukan pasca 15 menit pemberian premedikasi menggunakan ketamin (Ketamine-hameln ${ }^{\circledR}$ ) melalui injeksi subcutan dengan dosis 22-30 mg/kg BB;

3) Pra-incisi. Sebelum dilakukan tindakan, anjing diposisikan rebah sinister dan rambut pada sekitar mata bagian kanan dipotong menggunakan gunting untuk meminimalisir adanya kontaminasi dan tidak mengganggu selama tindakan operasi berjalan, serta dilakukan sterilisasi menggunakan antiseptik pada area tersebut.

4) Pengambilan larva dilakukan secara manual menggunakan pinset anatomis sampai bersih dan dilakukan pembilasan menggunakan $\mathrm{NaCl}$ fisiologis;

5) Selanjutnya dilakukan penjahitan sederhana antara $\pm 3 \mathrm{~mm}$ dari kelopak mata atas dan $\pm 3 \mathrm{~mm}$ kelopak mata bawah dan benang yang bertautan ditarik ke atas untuk kemudian dilakukan incisi konjungtiva $360^{\circ}$ menggunakan blade no.23, selanjutnya dilakukan preparasi tajam menggunakan gunting Metzenbaum untuk memisahkan bola mata dengan konjungtiva dan kapsula tenon. Nervus opticus dan pembuluh darah orbita dijepit menggunakan arteri klem bengkok;

6) Pemotongan bola mata dilakukan dengan memotong nervus opticus, otot intraokuler, melepaskan konjungtiva, dan pembuluh darah 
orbita yang dilakukan dengan menggunakan cautter (Gambar 1);

7) Ligasi dilakukan secara maksimal menggunakan chromic catgut no.03 dan menggunakan cautter yang bertujuan mengurangi kemungkinan terjadinya perdarahan, dilanjutkan dengan pembilasan cavum orbitalis menggunakan $\mathrm{NaCl}$ fisiologis, untuk menyerap sisa $\mathrm{NaCl}$ fisiologis menggunakan kasa steril;

8) Pemberian antibiotic enbatic tabur pada cavum orbitalis, kemudian dilanjutkan dengan melakukan penutupan cavum orbitalis. Jahitan pada subcutan menggunakan jahitan simple continuous dengan benang chromic catgut no.03 dan pada cutan menggunakan jahitan simple interrupted dengan benang chromic catgut no.02;

9) Pasca tindakan operatif dilakukan pemberian obat per injeksi intramuscular Dexamethasone dengan dosis $0,5-1 \mathrm{mg} / \mathrm{Kg}$ BB dan Seftriakson dengan dosis $25 \mathrm{mg} / \mathrm{Kg}$ BB. Selain itu diberikan terapi sistemik menggunakan obat per oral:

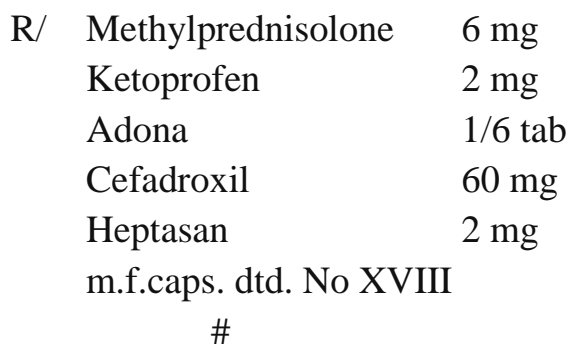

\section{HASIL DAN PEMBAHASAN}

Tindakan enukleasi metode subkonjungtival memudahkan untuk menjangkau nervus opticus dan pembuluh darah, namun meminimalkan pengankatan musculus sehingga faktor estetika tetap terjaga karena cavum orbita tidak tampak kosong. Enukleasi metode subkonjungtival dilakukan dengan mengangkat jaringan lacrimal, tindakan ini bertujuan mencegah adanya produksi air mata apabila kelenjar ada yang tersisa, sedangkan jalan pembuangan air mata telah buntu (Al-Antary et al., 2018).

Ophthal myiasis eksterna mengacu pada infestasi jaringan okular superfisial, biasanya penderita merasakan adanya sensasi benda asing dan pergerakan larva mungkin terasa dan nampak beberapa gejala: mata merah, fotofobia, hperemia konjungtiva, perdarahan konjungiva. Ophtal miasis interna merupakan keadaan ketika infestasi melibatkan anterior atau posterior segment bola mata. Komplikasi ophthal myiasis eksterna memungkinkan terjadinya ophtal miasis interna. Larva lalat dapat terlihat di anterior segment, ruang vitreous, dan sub retinal serta larva dapat menembus sklera dan bermigrasi ke mata. Mata merah, kehilangan penglihatan, nyeri mata, dan skotoma adalah gejala yang timbul pada ophtal miasis interna (Otranto et al., 2009).

\section{Patogenesis Ophtal Myasis}

Kondisi opthal myasis umumnya sering diawali dengan adanya trauma yang menyebabkan terjadinya kornea ulcer. Seiring waktu jika proses keradangan awal tidak diketahui maka akan mengundang lalat, dan dalam waktu 12- 24 jam, telur akan menetas menjadi larva yang selanjutnya akan masuk ke dalam jaringan (Wardhana, 2006).

Larva menggunakan mulut khusus untuk menembus kulit. Seiring waktu, belatung dapat mulai mengeluarkan racun yang dapat menyebabkan demam, lesu, dan syok. Infestasi myiasis menyebabkan iritasi, gangguan pada hewan dan gangguan kebiasaan normal termasuk istirahat, makan, dan pencernaan. Dengan infestasi yang parah, anjing itu bisa kaget. Goncangan disebabkan oleh enzim dan zat beracun yang dikeluarkan oleh belatung (Rahman et al., 2017).

Nyeri ringan dan peradangan biasanya berlangsung selama 10 hari (Eyigor et al., 2008). Peradangan ini menyebabkan suhu tubuh mengalami peningkatan, keadaan ini dikarenakan terjadi peningkatan aliran darah (hyperemia) (Ahmed, 2011). Perdarahan dapat terjadi karena larva mengikis jaringan yang dilalui oleh pembuluh darah (Francesconi dan Lupi, 2012). Aktivitas larva dalam jaringan menyebabkan kerusakan jaringan semakin parah dan area luka menjadi lebih luas, sehingga luka menghasilkan aroma busuk yang mengundang lalat lain serta dapat memicu terjadinya infeksi sekunder (Wardhana, 2006). 


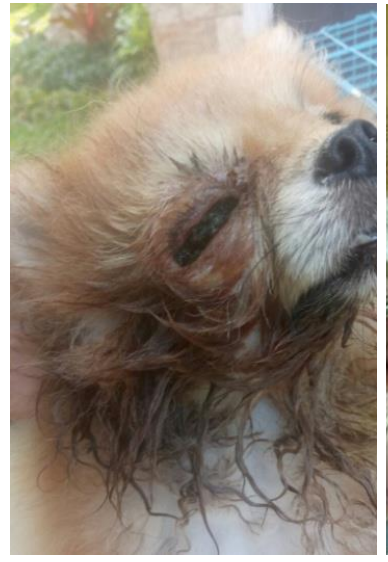

(a)

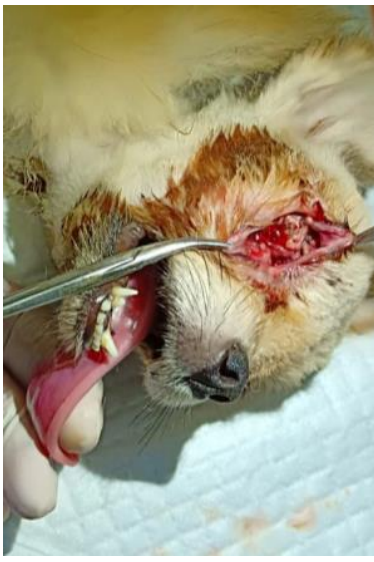

(b)

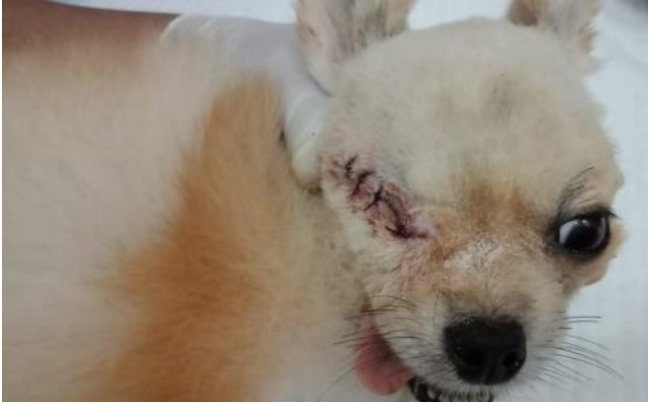

(c)

Gambar 1. a) Keadaan fisik pre-operatif; b) Post pengambilan bulbus oculi; c) Penjahitan dan penutupan cavum orbitalis

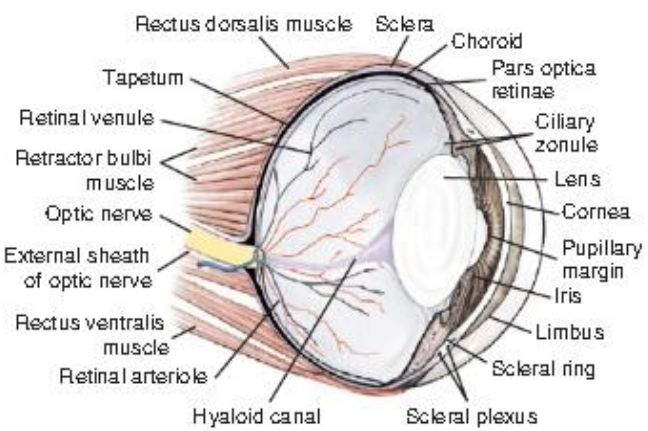

(d)

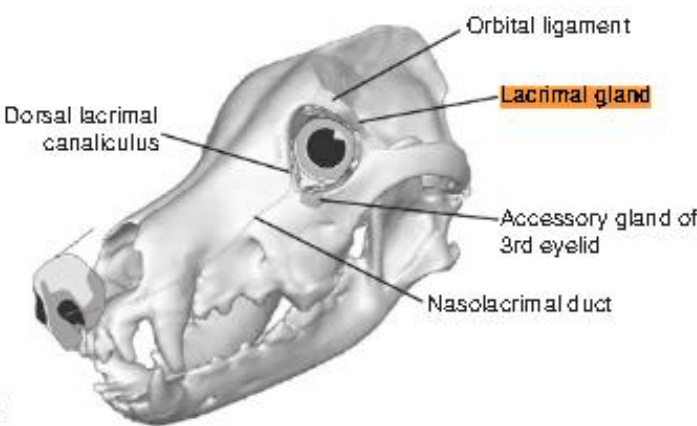

(e)

Gambar 2. d) Jaringan pengikat bulbus ocular; e) Anatomi kelenjar lakrimal (Murphy et al., 2012)

\section{Struktur Anatomi Mata}

Mata merupakan salah satu organ vital yang di dalamnya terdapat bola mata, kelenjar lacrimal, dan beberapa jaringan lain. Kerusakan pada mata akibat trauma maupun infeksi yang telah mengakibatkan kerusakan pada bola mata perlu dilakukan tindakan operasi yang bertujuan untuk memperbaiki kerusakan atau dilakukan pengambilan bola mata akibat perlukaan yang menyebabkan kematian jaringan.

Bola mata anjing berbentuk hampir bulat dan memiliki ukuran bervariasi berdasarkan ras, tetapi rata-rata berdiameter antara 20-22 $\mathrm{mm}$. Otot penggantung bola mata anjing terdiri dari m. rectus dorsalis, m.retractor bulbi, m. rectus ventralis. Mata mendapatkan inervasi dari $\mathrm{n}$. opticus dan divaskularisasi oleh arteri dan vena orbitalis. Selain itu juga terdapat kelenjar lakrimal yang berwarna merah muda, berbentuk oval, terletak jauh ke periorbita pada superiolateral bola mata (Gambar 2) (Murphy et al., 2012).

\section{Terapi}

Terapi yang diberikan berupa antibiotik, antiinflamasi, antihemoragi, analgesik, dan antihistamin. Seftriakson (Ceftriaxone sodium ${ }^{\circledR}$, Phapros, Indonesia) digunakan untuk mengobati infeksi serius dan berperan sebagai antibiotik, dalam terapi ini pemberian seftriakson secara inta muskular diberikan satu kali pasca operasi berlangsung. Penggunaan dexametason (Dexamethasone ${ }^{\circledR}$, Phapros, Indonesia) yang merupakan agen inflamasi juga diberikan satu kali pasca operasi menggunakan injeksi intra muskular. Menurut Plumb (2008), penggunaan dexametason umumnya tidak boleh digunakan sendiri dalam pengobatan kekurangan adrenal, karena dexamethason memiliki efek mineralokortikoid.

Antiinflamasi lainnya yang digunakan adalah methylprednisolon yang diberikan per oral, agen antiinflamasi dapat diberikan secara oral atau parenteral, efektifitas obat ini relatif lebih tinggi 5 kali lipat dari kortisol (Islami et 
al., 2018). Penggunaan ketoprofen yang merupakan antiinflamasi nonsteroid lainnya yang memiliki aktivitas antipiretik, analgesik, dan antiinflamasi. Mekanisme kerjanya adalah menghambat katalisis siklooksigenase asam arakidonat terhadap prekursor prostaglandin (endoperoksida), sehingga menghambat sintesis prostaglandin dalam jaringan (Plumb, 2008).

Adona (Carbazochrome) adalah agen antihemoragi yang digunakan untuk menghentikan aliran darah dari luka dengan meningkatkan agregasi trombosit dan menginduksi trombosit untuk membentuk sumbat. Obat ini digunakan untuk mengontrol perdarahan jika terjadi trauma, pembedahan dan pendarahan usus. Obat ini bertindak sebagai agen antihemoragi karena berinteraksi dengan adrenoceptor yang terletak di platelet. yang terakhir adalah G-coupled protein binding yang mengarah pada peningkatan konsentrasi kalsium intraseluler yang menyebabkan platelet melepaskan faktor seperti serotonin, ADP, Von Willebrand dan faktor pengaktif platelet yang menginduksi agregasi (Ghareeb and Karaman., 2015).

Antibiotik lain yang digunakan dalam terapi adalah cefadroxil yang diberikan secara per oral. Plumb (2008) menyatakan, obat ini bertindak sebagai antibiotic spectrum luas yang bekerja dengan menghambat pembentukan dinding sel bakteri. Cefadroxil dapat diserap dengan baik setelah pemberian oral pada anjing. Selain itu diberikan heptasan (Cyproheptadine $\mathrm{HCl}$ ) secara per oral yang bertindak sebagai antihistamin, obat ini bekerja bersaing dengan histamin pada sel efektor. Antihistamin ini tidak menghalangi pelepasan histamin, tetapi dapat memusuhi efeknya (Plumb, 2008). Penggunaan obat yang pemberiannya secara per oral diberikan sesuai dengan resep yang telah dianjurkan oleh dokter dan diimbangi dengan memantau perkembangan kesehatan anjing tersebut.

\section{Analisa Kesembuhan}

Prognosa pada kasus yang dialami anjing Kino adalah fausta. Proses penyembuhan pada kasus ini dapat berlangsung selama 14 hari. Sesuai dengan pernyataan Mitchell (2008), menyatakan bahwa pasien perlu menggunakan Elizabeth chollar sampai luka operasi pada kelopak mata membaik yang membutuhkan waktu antara \pm 14 hari, penggunaan Elizabeth cohollar juga bertujuan untuk mencegah selftrauma. Beberapa pembengkakan orbital mungkin terjadi, biasanya karena pembentukan hematoma di bawah kelopak mata tertutup. Namun, dapat pulih dalam tiga hingga lima hari dengan memberikan kompres hangat secara rutin yang diterapkan oleh owner.

Terdapat beberapa faktor yang mempengaruhu waktu kesembuhan seperti tata laksana operasi yang lage artis, pemberian obat post operasi secara teratur, grooming rutin, serta penting memantau pertumbuhan rambut di area sekitar luka. Kemungkinan adanya sisa belatung dan kelenjar air mata yang masih tertinggal di dalam cavum orbita.

Beberapa komplikasi post operatif pada tindakan enucleasi bulbi yang mungkin terjadi antara lain: infeksi, perdarahan post operasi, terbukanya luka bedah, dan emphysema orbitalis.

\section{Pencegahan}

Sanitasi yang buruk dapat menjadi predisposisi lalat sehingga probabilitas untuk menginfestasi semakin besat. Beberapa pencegahan yang perlu dilakukan adalah manajemen pemeliharaan yang baik, rutin membersihkan kandang dan lingkungan area kandang, grooming rutin, serta kepekaan owner terhadap adanya perubahan keadaan hewan peliharaan juga penting sehingga tidak terjadi keterlambatan penanganan kasus.

\section{KESIMPULAN}

Berdasarkan serangkaian pemeriksaan yang telah dilakukan yaitu didapatkan suhu tubuh $39,8^{0} \mathrm{C}$, frekuensi pulsus $107 \mathrm{kali} / \mathrm{menit}$, frekuensi nafas sebanyak $27 \mathrm{kali} / \mathrm{menit}$, turgor normal, dan refleks pupil mata sebelah kiri normal, serta mata sebelah kanan terdapat koloni belatung dan beraroma busuk, maka anjing ras Pomeranian ini didiagnosa menderita ophtal miyasis. Prognosa dari kasus ini adalah fausta. 
Tindakan yang dilakukan dalam menangani kasus ini adalah melalui tindakan operatif enukleasi bulbi. Tingkat kepedulian owner terhadap perubahan keadaan fisik hewan penting ditegakkan, serta perlu diperhatikan manajemen pemeliharaannya.

\section{UCAPAN TERIMA KASIH}

Kami mengucapkan terima kasih kepada Klinik Hewan Sahabat Satwa Genteng, Banyuwangi telah mengizinkan kami untuk turut serta dalam tindakan enukleasi bulbi pada anjing ras Pomeranian dalam kasus ophtal myasis serta atas ilmu yang telah disampaikan.

\section{DAFTAR PUSTAKA}

Ahmed, A.U. 2011. An Overview Of Inflammation: Mechanism And Consquences. Monash University. Australia. Font. Biol., 6(4), 274-281.

Al-Antary, T.M., Nazzal, R.M., Al-Antary, E.T. 2018. Ophthalmic Myasis Externa Caused by Larva Of The Sheep Nasal Botfly Oestrus ovis L. (Diptera:Oestridae) In Jordan. Fresenius Environmental Bulletin, 27(3), 1923-1927.

Berenji, F., Hosseini-Farash, B.R., MarviMoghadam, N. 2014. A Case of Secondary Ophthalmomyiasis Caused by Chrysomya bezziana (Diptera: Calliphoridae). J. Athropod. Born Dis., 9(1), 125- 130.

Eyigor, H., Dost, T., Dayanir, V., Basak, S., Eren, H. 2008. A Case of Naso-Opthalmic Myasis. Kulak Burun Bogas Ihtis. Derg. 18, 371- 373.

Francesconi, F., Lupi, O. 2012. Myiasis. Clin. Microbiol. Rev., 25(1), 79-105.

Ghareeb, H., Karaman, R. 2015. AntiHemorrhagic Agents. Chapter 6. Nova Science Publisher Inc. p201-217. ISBN: 978-1-63462-828-9.
Islami, D.N., Dewi, C.M.S., Triana, N.M., Purnama, M.T.E. 2018. Laporan Kasus: Otitis Eksterna dan Auricular Hematoma (Othematoma) pada Anjing Samoyed. J. Med. Vet., 1(3), 80-86.

Mitchell, N. 2008. Enucleation In Companion Animals. Irish Vet. J., 61(2), 108-114.

Mullen, G.R., Durden, L.A. 2001. Medical And Veterinary Entomology. 2nd Edition. Academic press: San Diego.

Murphy, C.J., Samuelson, D.A., Pollock, R.V.H. 2012. The Eye. Miller's Anatomy of The Dog. Chapter 21. p746-785.

Otranto, D., Cantacessi, C., Santantonio, M., Rizzo, G. 2009. Oestrus Overcausing Human Ocular Myasis: From Countryside to Town Centre. Clin. Exp. Ophthalmol., 37, 327-328.

Plumb, D.C. 2008. Veterinary Drug Handbook. 6th Edition. Pharma Vet Inc. p143-144; p166-168; p240-241; p265-269; p51-522; p600-603.

Rahman, M.S., Yadav, S.K., Hasan, T., Dutta, A., Chowdhury, S., Sharkar, S. 2017. Defferent Clinical Conditions and Evaluation of Factors Responsible for Myiasis in Pet Dogs in Bangladesh. Res. J. Vet. Pract., 5(3), 28-33.

Shinohara, E.H., Martini, M.Z., Oliveira, N., Takahashi, A. 2004. Oral Myiasis Treated With Ivermectin. Case Report. Braz. Dent. J., 15(1), 79- 81.

Wakamatsu, T.H., Pierro-Filho, P.T. 2006. Opthalmomyiasis Externa Caused by Dermatobia Hominis: A Successful Treatment With Oral Invermectin. Eye (Lond). 20, 1088-1090.

Wardhana, A.H. 2006. Chrysomya bezziana Penyebab Myiasis Pada Hewan dan Manusia: Permasalahan dan 
Penanggulangannya. Wartazoa. Balai Veterinary Practicioner. 2nd Edition. Penelitian Veteriner. Bogor. 16(3), 146-159. Germany. Schliitersche Verlagsgesellschaft.

Wyman, M., Boeve, M.H., Neumann, W., Spiess, B. 2007. Opthalmology For The
Zumpt, F. 1965. Myiasis in Mand and Animal in the Old World. Butterworths, London. 15, 1267. 